\title{
Growth of Newly Established Tilia platyphyllos 'Rubra' Roadside Trees in Response to Weed Control and Pruning
}

\author{
Palle Kristoffersen, Oliver Bühler, Søren Ugilt Larsen, and Thomas Barfoed Randrup
}

\begin{abstract}
This tree establishment study investigates the effect of weed control and pruning treatments on stem and branch diameter increment of newly planted broad-leaved lime (Tilia platyphyllos 'Rubra') roadside trees.

Weed control significantly increased stem circumference four years after establishment by $3.6 \mathrm{~cm}$ ( $1.4 \mathrm{in})$ from $24.5 \mathrm{~cm}(9.7 \mathrm{in}, \mathrm{untreated}$ control) to 28.1 $\mathrm{cm}(11.1 \mathrm{in})$. In terms of Danish nursery sales prices, this corresponds to an increase of tree cash value of $1201 \mathrm{DKK}(160.90 €, 235.40 \mathrm{US} \$)$ per tree. Calculating with $400 \mathrm{DKK}(53.60 €, 78.40 \mathrm{US} \$)$ as cost for contract weeding per hour, this corresponds to 0.75 hours per tree per year for a period of four years.

In addition to weed control treatments, trees were pruned at establishment, two years after establishment, or at both times. None of the pruning treatments affected stem diameter growth, but branch diameter and branch:stem diameter ratio were significantly reduced by all pruning treatments. Branch diameter ranged from $40.1 \mathrm{~mm}$ (1.6 in) on unpruned trees to $34.6 \mathrm{~mm}$ (1.4 in) on trees pruned both times. Branch:stem diameter ratio ranged from 0.54 on unpruned trees to 0.49 on trees pruned both times.

In consequence, weed control is recommended as a strong management practice. Mild pruning is also considered advisable, if structural crown problems can be avoided at an early stage, and if the tree has to be prepared for later pruning operations.

Key Words. Branch Diameter Growth; Branch:Stem Ratio; Establishment Care; Linden; Stem Diameter Growth; Transplanting; Tree Valuation.
\end{abstract}

The period immediately following planting of roadside trees at their final site is often critical for their successful development. During the production phase in nurseries, trees are irrigated, fertilized, and pruned on a regular basis and competing vegetation is controlled (Krüssmann 1997). On the final site, trees often have to cope with much poorer growth conditions as well as reduced maintenance and care (Harris 2007). In this study, approaches to support tree establishment and development on the final site are investigated in regard to their effect on stem and branch growth: weed control, corrective pruning before planting, and formative pruning during the establishment period.

\footnotetext{
Weed Control

Newly transplanted trees often experience growth depressions during the first growth periods at their final sites, to a large extent caused by the loss of root biomass during the transplanting process (Solfjeld and Hansen 2004). Although information about the extent of root loss is not entirely consistent and depends on the production method, there is little doubt that trees planted bare-rooted or balled \& burlapped lose roots during harvest (Watson and Sydnor 1987; Gerhold and Johnson 2003; Anella et al. 2008; Struve 2009). Therefore, newly planted roadside trees are particularly sensitive to competition from other vegetation (Watson 1988; Green 1989; Samyn and De Vos 2002; Groninger et al. 2004; Stewart et al. 2005). Control of competing vegetation is supposed to reduce the effects of the transplant shock and to contribute to a fast and successful establishment. Weed management may consist of several approaches, including
}

applications of herbicides, mechanical or thermal weed control or mulching with different organic or inorganic materials. In Denmark, the use of herbicides in public areas is strictly regulated. Municipalities therefore rely on mulching and thermal or mechanical weed control measures (Kristoffersen et al. 2008a).

\section{Pruning}

In European nurseries, trees are normally pruned when they are transplanted during the production process (Krüssmann 1997). The removal of shoots increases the root:shoot ratio and consequently reduces the foliage area that has to be supported by the recovering root system (Watson 1991; Findlay 1997). In this manner, pruning is meant to alleviate drought stress and increase transplanting success, especially on difficult sites and/or sites with reduced care and maintenance (Ranney et al. 1989). However, as severe shoot pruning negatively affects tree growth ( $\mathrm{Li}$ et al. 2001) and transplanted trees respond to root loss with a reduction of leaf area in a self-regulating process (Kjelgren and Cleveland 1994), pruning of transplanted trees remains controversial.

In the following, pruning shortly before or at transplanting is referred to as corrective pruning.

The main purpose of later pruning operations is formation of a healthy and sustainable crown structure suitable for the present location. For roadside trees, this often includes crown-lifting in accordance to traffic requirements. In Denmark, the required clearance over roads is $4.5 \mathrm{~m}(14.8 \mathrm{ft})$, implying that many branches of newly transplanted trees are temporary and will have to be removed later. In order to minimize damage, prun- 
ing guides generally recommend minimizing the wound surface. The Danish Tree Pruning Guide recommends removing branches only when the branch diameter is less than one-third stem diameter (Dansk Træplejeforening 2000), and German guidelines recommend that branches in conflict with clearance regulations should not exceed a branch diameter of $5 \mathrm{~cm}$ (2 in) (FLL 2006). One of the main purposes of these pruning operations is therefore to reduce diameter growth of lower, temporary branches and thus prepare them for a later removal. This type of pruning after planting is referred to as formative pruning in the following.

Thus, weed control and pruning during the critical establishment phase have the overall objective to improve the chances of roadside trees to survive the first years after transplanting and develop into functioning roadside trees. The aims of this study are to investigate how both maintenance options 1) influence tree growth during establishment, 2) determine whether later pruning operations can be prepared and facilitated by early corrective pruning in order to reduce branch:stem ratio, and 3) provide an opportunity to discuss economic aspects of weed control of newly planted trees.

\section{MATERIAL AND METHODS}

\section{Test Site and Plant Material}

The investigation was carried out on a newly planted, rural roadside plantation on Hindsgavl Allé $\left(55^{\circ} 30^{\prime} \mathrm{N}, 9^{\circ} 41^{\prime} \mathrm{E}\right)$ near the town Middelfart, Denmark. Average annual precipitation in the area is 639 $\mathrm{mm}$ (25.16 in), based on measurements in the period 1961-1990 (DMI 2005). Precipitation was below the average in 2003 (481 $\mathrm{mm}, 18.94$ in) (DMI 2004), and above the average in 2002 (724 mm, 28.5 in) and 2004 (737 mm, 29 in) (DMI 2003; DMI 2005).

Forty Tilia platyphyllos 'Rubra' roadside trees were planted in two planting strips on both sides of the road with 20 trees on each side. The trees were planted in the existing soil profile, a sandy loam with good drainage. The trees were delivered from the nursery balled \& burlapped with a stem circumference of $12-14 \mathrm{~cm}(4.7-5.5 \mathrm{in})$ at $1 \mathrm{~m}(3.3 \mathrm{ft})$ stem height. The root ball was positioned in the middle of a $1 \mathrm{~m} \mathrm{x} 1 \mathrm{~m}$ x $0.6 \mathrm{~m}$ ( $3.3 \mathrm{ft}$ x $3.3 \mathrm{ft} \times 2 \mathrm{ft}$ ) planting hole, stabilized with packed soil and the planting hole was refilled with uncompacted backfill soil. No fertilizers, soil amendments or mulch materials were used. The burlap covering the root ball was decomposable and was not removed during planting. After planting, the upper surface of the root ball was just visible. Trees were planted with a distance of $8 \mathrm{~m}(26.3 \mathrm{ft})$ between trees and $2.5 \mathrm{~m}(8.2 \mathrm{ft})$ to the road.

The trees were planted in early spring 2001 . All trees were irrigated twice with $100 \mathrm{~L}$ (26.4 gal) of water in both 2001 and 2002. Four trees failed to establish in spring 2001. No treatments but corrective pruning had been executed at that time: two of the failed trees were pruned, the remaining two unpruned. The replacement trees were excluded from the data analysis.

\section{Treatments}

\section{Weed control}

Weed control was carried out with a portable blow torch. Weeds were controlled from 2001-2004 such that no weeds were present on an area of $1 \mathrm{~m} \times 8 \mathrm{~m}(3.3 \mathrm{ft} \times 26.3 \mathrm{ft})$ around the tree during the period of the experiment. Weed control was executed on 20 trees, the remaining 20 trees served as untreated control. Gramineous weeds dominated on the untreated control plots.

\section{Pruning}

Trees received the following pruning treatment combinations: 1) corrective pruning at the time of planting, 2) formative pruning two years after planting, 3) both corrective and formative pruning, and 4) untreated control.

Corrective pruning was executed so that second order lateral branches were removed immediately before planting of the trees. Formative pruning was executed once in 2003, two years after planting, and included reduction cuts (cutting to a lateral) of lower lateral branches in order to slow their diameter growth and prepare the trees for later crown raising. None of the pruning treatments caused foliage reductions of more than $30 \%$.

\section{Experimental Design}

The experiment comprised 40 trees in total, 20 on each side of the road. The test site was organized in 5 blocks of eight trees each (four trees on each side of the street) in order to account for possible variations of soil conditions along and across the road.

The investigation was designed as a split-plot experiment with weed control as whole plot factor and pruning as subplot factor.

As weed control and pruning were executed by municipal gardeners unacquainted with experimental work, treatments were distributed systematically in order to ensure correct treatments. In addition, the distance between individual trees was considered large enough to limit the risk of neighbor effects, and the advantages of a systematic treatment distribution were therefore considered to compensate for drawbacks.

In each block, weed control was executed in whole plots on one side of the street (four trees), while the four control trees were in the whole plot on the other side of the street. This pattern alternated from block to block. The four pruning treatments were assigned systematically to one tree within each whole plot (i.e., a subplot consisted of one tree).

\section{Measurements}

Stem circumference at $1 \mathrm{~m}$ above ground was measured after cessation of the growth period in 2002, 2003, and 2005. Branch diameter of the two lowest branches was measured at the base of the branch in 2005 .

\section{Data analysis}

A regression model was used to describe the development of stem circumference over time in response to weed control, corrective pruning and interaction effects. The analysis was based on a linear mixed model approach (MIXED procedure in SAS 9.1) and included data from 2002, 2003, and 2005. Formative pruning was omitted from the model, as formative pruning treatments started late in the test period in 2003. Block was included in the model as random effect.

To attain uniformity of variance, the response variable stem circumference was transformed to its reciprocal value $(1 / \mathrm{cm})$. For the purpose of graphical presentation, the reciprocal value was then transformed back into the original scale (Figure 1).

In a second model, the effects of weed control and pruning treatments on branch diameter and branch:stem ratio in 2005 were analyzed, and a third model analyzed pruning effects on stem diameter in 2005. Both models included 2005 data only and were based on a mixed linear model approach (MIXED procedure 


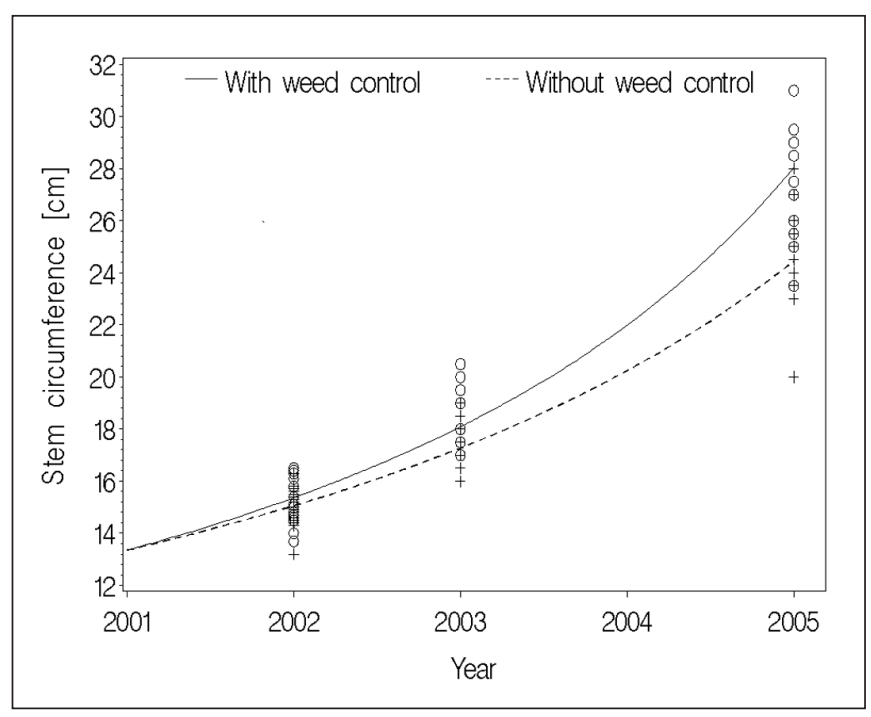

Figure 1. Growth curves for roadside lime trees (Tilia platyphyllos 'Rubra') with and without weed control based on regression equations (1): $1 / y=0.07493-0.00851 x$, and (2): $1 / y=0.07493-0.00982 x$. For this figure, the reciprocal response variable stem circumference was transformed back to its original scale. Single observations are depicted as "o" (weed control) and "+" (without weed control).

in SAS 9.1). The response variables were analyzed in response to the whole plot factor weed control, the subplot factor pruning and interaction effects. Block was included as random effect.

For all models, uniformity of variance was tested by visual inspection of residual plots produced with the SAS procedure GLM.

In order to estimate the market value of trees with different weed control treatments four years after establishment, 2008 price and size information of three Danish tree nurseries was collected to describe the relationship between stem circumference and price. The relationship was analyzed with a nonlinear regression analysis with price as response variable and stem circumference as explanatory variable (NLIN procedure in SAS 9.1). Monetary values are quoted in Danish crowns (DKK), Euros (€) and U.S. Dollars (US\$), using the annual mean exchange course for 2008 provided by the National Bank of Denmark ( 1 DKK equates $0.134 €$ and 0.196 US\$).

\section{Results}

\section{Weed control}

Weed control had significant $(P<0.0001)$ effects on the slope of the reciprocal growth curves and thus on stem diameter growth of the test trees. The growth curves were neither significantly affected by corrective pruning $(P=0.1634)$ nor by interaction effects $(P=0.6642)$. No significant differences in estimated start diameter $[13.3 \mathrm{~cm}$ (5.24 in) on the original scale] were determined $(P=0.9504)$. According to the regression analysis, reciprocal stem circumference for trees subjected to weed control can thus be described by Equation 1, whereas reciprocal stem circumference for the untreated control trees is described by Equation 2: where $\mathrm{y}$ denotes stem circumference and $\mathrm{x}$ denotes year after planting.

Transformed back to original scale, estimated stem circumference in 2005 corresponds to $28.1 \mathrm{~cm}$ (11.1 in) for trees subjected to weed control and to $24.5 \mathrm{~cm}$ (9.7 in) for the untreated control trees. Stem circumference difference between the treatments is $3.6 \mathrm{~cm}$ (1.4 in), corresponding to $1.2 \mathrm{~cm}(0.5 \mathrm{in})$ in stem diameter.

Weed control effects on branch diameter were analyzed in a separate model, determining that 2005 branch diameter was significantly larger on the trees in weed control plots [38.5 mm (1.5 in)], compared to untreated plots [34.6 $\mathrm{mm}(1.4 \mathrm{in})](P=0.0002)$, but branch:stem diameter ratio was not affected significantly by weed control $(P=0.83)$.

\section{Pruning}

All pruning treatments reduced branch diameter significantly $(P=0.006)$ and resulted in significantly reduced branch:stem diameter ratio $(P=0.048)$ four years after planting (Table 1). None of the pruning treatments had significant effects on stem diameter growth $(P=0.08)$.

\section{Increase of value}

In order to quantify the added value gained by weed control, 2008 prices for Tilia platyphyllos 'Rubra' of three prominent Danish tree nurseries were plotted against size (described as midpoint of each size class [e.g., $12-14 \mathrm{~cm}(4.7-5.5 \mathrm{in})$ is converted to $13 \mathrm{~cm}$ (5.1 in)]. A regression analysis showed that the price development of nursery trees can be described by the following equation for the size range $10-12 \mathrm{~cm}(3.9-4.7 \mathrm{in})$ to $35-40 \mathrm{~cm}(13.8-15.7 \mathrm{in})$ :

[Equation 3] $\quad \mathrm{y}=2.2675 \mathrm{x}^{2.2752}$

where y denotes the price in 2008 , and $\mathrm{x}$ denotes stem circumference size (Figure 2). According to this, the size difference between trees subjected to weed control $(28.1 \mathrm{~cm}$, corresponding to 4484 DKK, $600.80 €, 878.90$ US\$) and trees without weed control $(24.5 \mathrm{~cm}$, corresponding to $3282 \mathrm{DKK}, 439.80 €$, 643.30 US\$) amounts to a cash value of 1201 DKK (160.90€, 235.40 US\$). If this amount is distributed over the period of four years, it is equivalent to 300 DKK/year (40.20€, 58.80 US\$) or, if the cost of contract weeding is set at 400 DKK per hour (53.60 €, 78.40 US $\$$, standard cost in Denmark), 0.75 working hour per tree per year.

Table 1. Estimates of branch diameter and branch:stem ratio of roadside lime trees (Tilia platyphyllos 'Rubra') four years after planting in response to corrective and formative pruning treatments (LSMEANS \pm standard error). Values differ significantly when followed by different letters (LSD test, $P<0.05$ ).

\begin{tabular}{llll}
\hline Corrective pruning & Formative pruning & $\begin{array}{l}\text { Branch diameter } \\
{[\mathrm{mm}]}\end{array}$ & $\begin{array}{l}\text { Branch:stem } \\
\text { diameter ratio }\end{array}$ \\
\hline- & - & $40.1( \pm 1.29) \mathrm{a}$ & $0.54( \pm 0.017) \mathrm{a}$ \\
+ & - & $36.7( \pm 1.29) \mathrm{b}$ & $0.50( \pm 0.017) \mathrm{b}$ \\
- & + & $34.8( \pm 1.29) \mathrm{b}$ & $0.49( \pm 0.017) \mathrm{b}$ \\
+ & + & $34.6( \pm 1.29) \mathrm{b}$ & $0.49( \pm 0.017) \mathrm{b}$ \\
\hline
\end{tabular}

[Equation 1] $\quad 1 / \mathrm{y}=0.07493-0.00851 \mathrm{x}$

[Equation 2] $\quad 1 / \mathrm{y}=0.07493-0.00982 \mathrm{x}$ 


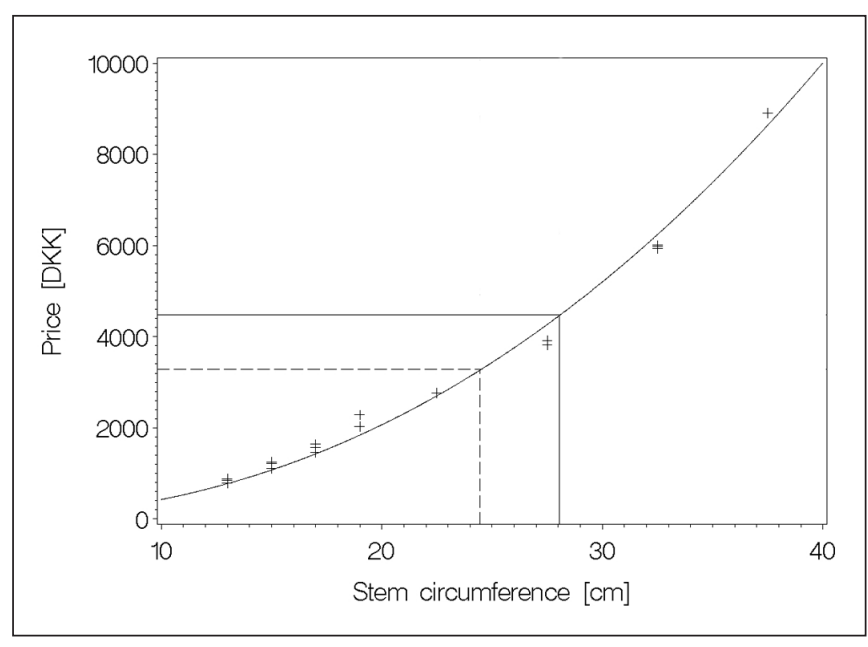

Figure 2. Nursery prices of lime (Tilia platyphyllos 'Rubra') depending on size in Denmark. Reference lines designate size and price of test trees with weed control (solid line) and without weed control (dashed line).

\section{DISCUSSION}

\section{Weed Control}

The presented results provide evidence of the highly beneficial effect of weed control on tree growth. This is in accordance with a number of studies in arboriculture and forestry (Watson 1988; Samyn and De Vos 2002; Groninger et al. 2004; Stewart et al. 2005), and accentuates the importance of weed control to support establishment of roadside trees. Whereas different weed control techniques have proven to aid tree establishment, it may be worthwhile to consider techniques such as mulching that have additional beneficial effects (e.g., chemical and physical soil characteristics) (Chalker-Scott 2007).

The capitalized size increase of weed-controlled trees of 300 DKK ( $40.20 €, 58.80$ US\$), equivalent to $0.75 \mathrm{~h}$ per tree and year, is considered adequate to perform a strict weed control regime under Danish conditions: Assuming a minimum area capacity of portable blow torches of approximately $100 \mathrm{~m}^{2} / \mathrm{h}\left(120 \mathrm{yd}^{2} / \mathrm{h}\right)$ (Rannertshauser and Bertram 1999), the area controlled in 0.75 working hours corresponds to $75 \mathrm{~m}^{2}\left(89.7 \mathrm{yd}^{2}\right)$. For this study, the controlled area per tree was $8 \mathrm{~m}^{2}\left(9.57 \mathrm{yd}^{2}\right)$, implying that 0.75 hours would enable 9 visits $\left(75 \mathrm{~m}^{2}\right.$ divided by $\left.8 \mathrm{~m}^{2}\right)$. Earlier investigations by Kristoffersen et al. (2008b) with blow torches for weed control on traffic islands reported a total of eight treatments in the period from April to November sufficed to control weeds efficiently. It is therefore suggested that the cost of providing weed control during the establishment period of roadside lime trees was less than the resulting value increase of the trees during the first four years. Thus weed control provides a positive return on investment.

\section{Pruning}

In this study, neither pruning treatment had significant effects on stem diameter growth. If considered necessary, pruning can thus be applied without fearing negative consequences for tree growth in the establishment period. This can be the case if apparent problems in crown structure can be resolved early, if later pruning operations can be prepared and facilitated, in order to reduce suscep- tibility to wind damage (Gilman et al. 2008) or if it is intended to restore a disturbed root:shoot ratio. The importance of the latter is controversial, as it may be counterproductive to reduce the assimilation capacities by removing foliage if water and nutrition can be supplied in sufficient quantities (Kjelgren and Cleveland 1994). However, this may not be the case on the planting site, and here an artificial restoration of the root:shoot ratio may contribute to tree establishment and survival (Ranney et al. 1989; Findlay 1997).

The intensity of pruning operations is critical in regard to effects on tree growth. As reported by Li et al. (2001), severe pruning (removal of one-third to two-thirds of crown) of newly planted trees will result in reduced stem diameter growth, as assimilation capability is reduced and physiological processes are disturbed. In this study, pruning never even came close to this order of magnitude, and it could be argued the mild pruning performed here moved tree growth from undesired locations (lower lateral branches that have to be removed later to comply with clearance regulations), to desired locations (upper crown parts). Even with the mild pruning performed in this study there was some evidence that pruning may have affected stem diameter growth $(p=0.08)$. Therefore, stronger pruning operations presumably would have resulted in reduced stem diameter growth, too.

Although a combination of corrective and formative pruning reduced the branch:stem ratio from 0.54 to 0.49 , the desired ratio $(<0.33)$ described by the Danish Tree Pruning Guide (Dansk Træplejeforening 2000) was not reached. Moreover, the determined effect of pruning was only small. Similar branch:stem ratios on young linden trees ranging from 0.46 to 0.50 (two lowest lateral branches) are reported by Uehre and Cleusters (2006). It therefore seems doubtful whether young trees like the test trees can achieve the optimum branch:stem ratio of 0.33 at all.

However, the effect of the pruning operations on branch:stem ratio is likely to increase well beyond the test period. As carbohydrate production and growth is allocated to the upper, growing part of the crown, the lower branches will be shadowed, further reducing their assimilation potential and, in consequence, their growth.

Altogether, the lack of pronounced negative consequences for tree growth encourages mild pruning operations at or following tree establishment, focusing on preparation of crown raising and removal of structural problems.

\section{CONCLUSION}

Weed control in the first four years after planting had significant positive effects on stem diameter growth of lime trees. The costs of weed control during the establishment period can be balanced with the capitalized size increase achieved by weed control. Calculations based on nursery prices in Denmark indicate an increase in value by weed control during four years after planting corresponding to 0.75 hours of contract weeding per tree and year. This is supposed to be sufficient to effect strict weed control and even additional minor maintenance operations. Weed control can thus be considered as cost-effective. In addition to the known positive effects of weed control on tree establishment, urban forestry/ greenspace authorities are thus also provided with economic arguments in favor of maintenance operations promoting tree growth.

Neither pruning treatment had an effect on stem increment, but branch development was retarded by all treatments. Mild pruning operations proving beneficial at a later point in tree development are therefore considered feasible without risking 
growth reductions. The desired branch:stem ratio of less than 0.33 for safe removal of branches stated in Danish pruning recommendations, however, was not achieved by any treatment. In light of the presented results, this recommendation should be reconsidered and possibly related to specific tree age or species.

\section{LITERATURE CITED}

Anella, L., T.C. Hennessey, and E.M. Lorenzi. 2008. Growth of Balled and - Burlapped versus Bare - Root Trees in Oklahoma , U.S. Journal of Arboriculture 34:200-203.

Chalker-Scott, L. 2007. Impact of Mulches on Landscape Plants and the Environment-A Review. Journal of Environmental Horticulture 25:239-248.

Dansk Træplejeforening, 2000. Beskæring af træer. 19 pp.

DMI (2003): The Climate of Denmark, 2002. Technical report 03-02. Danish Meteorological Institute. Copenhagen, Denmark. 87 pp.

DMI (2004): The Climate of Denmark, 2003. Technical report 04-02. Danish Meteorological Institute. Copenhagen, Denmark. 87 pp.

DMI (2005): The Climate of Denmark, 2004. Technical report 05-01. Danish Meteorological Institute. Copenhagen, Denmark. 87 pp.

Findlay, C. 1997. Root and shoot pruning in root-balled Acer platanoides L.: effects of establishment and shoot architecture. Arboricultural Journal 21:215-229.

FLL. 2006. ZTV-Baumpflege. 71pp.

Gerhold, H.D., and A.D. Johnson. 2003. Root dimensions of landscape tree cultivars. Journal of Arboriculture 29:322-326.

Gilman, E.F., F. Masters, and J.C. Grabosky. 2008. Pruning affects tree movement in hurricane force wind. Arboriculture \& Urban Forestry 34:20-28.

Green, T.L. 1989. Effects of turfgrass and mulch on the establishment and growth of bare-root sugar maples. Journal of Arboriculture $15: 268-272$

Groninger, J.W., S.G. Baer, D.A. Babassana, and D.H. Allen. 2004. Planted green ash (Fraxinus pennsylvanica Marsh.) and herbaceous vegetation responses to initial competition control during the first 3 years of afforestation. Forest Ecology and Management 189:161-170.

Harris, J.R. 2007. Transplanting large trees. CAB Reviews: Perspectives in Agriculture, Veterinary Science, Nutrition and Natural Resources 2:1-7.

Kjelgren, R., and B.Cleveland. 1994. Growth and water relations of Kentucky coffee tree and silver maple following transplanting. Journal of Environmental Horticulture 12:96-99.

Kristoffersen, P., A.M. Rask, A.C. Grundy, I. Franzen, C. Kempenaar, J. Raisio, H. Schroeder, J. Spijker, A. Verschwele, and L. Zarina. 2008a. A review of pesticide policies and regulations for urban amenity areas in seven European countries. Weed Research 48:201-214.

Kristoffersen, P., A.Rask, and S.Larsen. 2008b. Non-chemical weed control on traffic islands: a comparison of the efficacy of five weed control techniques. Weed Research 48:124-130.

Krüssmann, G. 1997. Die Baumschule - Ein praktisches Handbuch für Anzucht, Vermehrung, Kultur und Absatz der Baumschulpflanzen. Parey Buchverlag im Blackwell Wissenschafts-Verlag, Berlin, 982 pp.

Li, M., P. Uehre, and J. Matschke. 2001. Diameter growth and stem form development of young trees, depending on pruning activity. Schweizerische Zeitschrift fur Forstwesen 152:389-393.

Rannertshauser, J., and A. Bertram. 1999. Thermische Verfahren der Unkrautregulierung. Rep. 0690. Thalacker Medien, Braunschweig.
Ranney, T.G., N.L.Bassuk, and T.H.Whitlow. 1989. Effect of transplanting practices on growth and water relations of 'Colt'cherry trees during reestablishment. Journal of Environmental Horticulture 7:41-45.

Samyn, J., and B. de Vos. 2002. The assessment of mulch sheets to inhibit competitive vegetation in tree plantations in urban and natural environment. Urban Forestry \& Urban Greening 1:25-37.

Solfjeld, I., and O.B. Hansen. 2004. Post-transplant growth of five deciduous Nordic tree species as affected by transplanting date and root pruning. Urban Forestry and Urban Greening 2:129-137.

Stewart, J.R., R. Kjelgren, P.G. Johnson, and M.R. Kuhns. 2005. Growth and water relations of littleleaf linden trees established in irrigated buffalograss and kentucky bluegrass. HortScience 40:1529-1533.

Struve, D.K. 2009. Tree Establishment: A review of some of the factors affecting transplant survival and establishment. Arboriculture and Urban Forestry 35:10-13.

Uehre, P., and T. Cleusters. 2006. Aktuelle Untersuchungen zum Lichtraumprofil, pp. 49-56. In: D. Dujesiefken and P. Kockerbeck (Eds.). Jahrbuch der Baumpflege 2006. Thalacker Medien, Braunschweig.

Watson, G.W. 1988. Organic mulch and grass competition influence tree root development. Journal of Arboriculture 14:200-203.

Watson, G.W., and T.D. Sydnor. 1987. The effect of root pruning on the root system of nursery trees. Journal of Arboriculture 13:126-130.

Watson, G.W. 1991. Attaining root:crown balance in landscape trees. Journal of Arboriculture 17:211-216.

\section{Palle Kristoffersen}

Senior advisor, Ph.D.

Division of Parks and Urban Landscapes

Danish Centre for Forest, Landscape, and Planning

Faculty of Life Sciences

University of Copenhagen

Rolighedsvej 23

DK-1958 Frederiksberg

Denmark

Oliver Bühler (corresponding author)

Ph.D.-student

Division of Parks and Urban Landscapes

Danish Centre for Forest, Landscape, and Planning

Faculty of Life Sciences

University of Copenhagen

Rolighedsvej 23

DK-1958 Frederiksberg

Denmark

Søren Ugilt Larsen

Development advisor, Ph.D.

AgroTech - Institute for Technology and Food Innovation

Udkarsvej 15

DK-8200 Aarhus $N$

Denmark

Thomas Barfoed Randrup

Head of Department, Ph.D.

NIRAS Consultants

Sortemosevej 2

DK - 3450 Allerød

Denmark 
Résumé. Cette étude sur la reprise des arbres s'intéresse aux effets du contrôle des mauvaises herbes et des traitements d'élagage sur la croissance en diamètre de la tige et des branches auprès de tilleuls à larges feuilles (Tilia platyphyllos 'Rubra') nouvellement plantés le long de rues.

Le contrôle des mauvaises herbes amène un accroissement significatif de la circonférence de la tige quatre après la plantation de $3,6 \mathrm{~cm}$, soit de 24,5 à 28,1 cm. En terme de prix de vente au Danemark, cela correspond à une augmentation de la valeur marchande de 1201 couronnes danoises $(160,9 €$ ou 235,40 \$ US) par arbre. En calculant un coût de 400 couronnes danoises à l'heure pour effectuer le travail de désherbage à contrat, cela correspond à 0,75 heure par arbre par année sur une période de quatre ans. En plus des mesures de contrôle des mauvaises herbes, les arbres ont été élagués soit lors de leur plantation, soit deux années après leur plantation ou encore à ces deux moments. Aucune des interventions d'élagage n'a eu d'effet sur la croissance en diamètre de la tige, mais le diamètre des branches ainsi que le ratio de diamètre branche:tige ont été significativement diminués avec tous les types d'élagage. Le diamètre de branche variait de $40,1 \mathrm{~mm}$ sur les arbres non élagués à $34,6 \mathrm{~mm}$ sur les arbres élagués deux fois. Le ratio de diamètre branche:tige variait de 0,54 pour les arbres non élagués à 0,49 pour les arbres élagués deux fois.

En conséquence, le contrôle des mauvaises herbes est recommandé comme pratique forte de gestion. L'élagage doux est aussi jugé comme opportun si des problèmes structuraux peuvent être éliminés au stade plus jeune et aussi si l'arbre doit être préparé pour des opérations d'élagage futures.

Zusammenfassung. Die Studie zur Standortetablierung von Bäumen untersucht den Einfluss von Unkrautbekämpfung und Baumschnitt auf Stamm- und Astdurchmesserzuwachs bei neu gepflanzten Sommerlinden entlang der Straße.

Die Unkrautkontrolle verstärkte nach vier Jahren deutlich den Stammumfang um 3,6 cm von $24,5 \mathrm{~cm}$ (unkontrollierte Kontrolle) bis 28,1 $\mathrm{cm}$. In dänischen Baumschulen konnte der Gewinn pro Baum gesteigert werden. Bei einem Preis von 400 DKK (53.6 €, 78.4 US\$) für AuftragsUnkrautbekämpfung/pro Stunde korrespodiert dieser Gewinn mit einem Aufwand von 0,75 h pro Baum in einer 4-Jahres-Periode. Zusätzlich zu der Unkrautbekämpfung erhielten die Bäume entweder einen Pflan- zschnitt oder nach zweiJahren einen Pflegeschnitt oder beides. Keine der Schnittmaßnahmen beeinflusste den Stammumfang, aber die Astdurchmesser und das Verhältnis Astdurchmesser: Stammdurchmesser wurden durch alle Schnittmaßnahmen signifikant reduziert. Der Astdurchmesser rangierte von 40,1 mm bei ungeschnittenen Bäumen bis hin zu 34,6 mm bei Bäumen, die beide Schnitte erhielten. Das Ast: Stammdurchmesser-Verhältnis rangierte zwischen 0,54 bei ungeschnittenen und 0,49 bei geschnittenen Bäumen.

Als Konsequenz empfiehlt sich die Unkrautbekämpfung als eine wichtige Kulturmaßnahme. Vorsichtiges Schneiden ist empfehlenswert, wenn strukturelle Kronenprobleme bereits in einem frühen Stadium verhindert werden können und der Baum für spätere Schnitte vorbereitet werden kann.

Resumen. Este estudio de establecimiento de árboles investiga el efecto del control de malezas y tratamientos de poda en el incremento del diámetro del tronco y rama de tilos (Tilia platyphyllos 'Rubra') recién plantados al lado de calles. El control de malezas incrementó significativamente la circunferencia del tallo, cuatro años después del establecimiento, por $3.6 \mathrm{~cm}$ (1.4 in), de $24.5 \mathrm{~cm}$ (9.7 in) a $28.1 \mathrm{~cm}$ (11.1 in), de control no tratados. En términos de los precios de venta daneses, esto corresponde a un incremento del valor de 1,201 DKK (160.9€, 235.4 US\$) por árbol. Calculando con 400 DKK (53.6 €, 78.4 US\$) como costo de deshierbe por hora, esto corresponde a 0.75 horas por árbol por año para un período de 4 años. Además de los tratamientos de malezas, los árboles fueron podados al momento del establecimiento, dos años después, o en ambas ocasiones. Ninguno de los tratamientos de poda afectó el crecimiento del diámetro del tronco, pero el diámetro de la rama y la relación diámetro rama:tallo fueron significativamente reducidos por todos los tratamientos de poda. El diámetro de la rama varió de $40.1 \mathrm{~mm}$ (1.6 in) en árboles no podados a $34.6 \mathrm{~mm}$ (1.4 in) en árboles podados las dos ocasiones. La relación diámetro rama:tallo varió de 0.54 en árboles no podados a 0.49 en árboles podados las dos veces. En consecuencia, el control de malezas es recomendado como una buena práctica de manejo. La poda suave es también considerada recomendable, si los problemas estructurales de copa pueden evitarse en etapas tempranas y si el árbol tiene que ser preparado para operaciones de poda posteriores. 